\title{
Anthocyanin Stability Profile of Mango Powder: Temperature, pH, Light, Solvent and Sugar Content Effects
}

\author{
Shireen Akther ${ }^{1, a, *}$, Farhana Sultana ${ }^{1, b}$, Md. Rahim Badsha ${ }^{1, \mathrm{c}}$, Jakia Sultana Jothi ${ }^{1, \mathrm{~d}}$, Md. Abdul Alim ${ }^{2, \mathrm{e}}$ \\ ${ }^{1}$ Department of Food Processing and Engineering, Chattogram Veterinary and Animal Sciences University, Khulsi-4225, Chattogram, \\ Bangladesh \\ ${ }^{2}$ Deapartment of Food Technology and Rural Industries, Bangladesh Agricultural University, Mymensingh, Bangladesh \\ *Corresponding author
}

A R T I C L I N F O A B S T R A C T

\section{Research Article}

Received : 05/04/2020

Accepted : 20/07/2020

Keywords:

Anthocyanins

Stability

Mango powder

Natural colorant

UV-VIS spectrophotometer
Anthocyanins, a major natural food colorant rich in mango powder, need considerable protection during processing and storage for better retention due to colour instability. The purpose of the study is to evaluate the stability of the anthocyanin's extracts obtained from cabinet dried mango powder under different factors which could disrupted the anthocyanin pigments during processing. The factors are processing temperature and time $\left(30^{\circ} \mathrm{C}, 60^{\circ} \mathrm{C}\right.$ and $80^{\circ} \mathrm{C}$ for 10,20 and 30 minutes each, respectively), storage conditions (room temperature, refrigerator temperature and freezing temperature), $\mathrm{pH}(2,3,4,7$ and 10), oxygen, influence of light, different extraction solvent (methanol, absolute ethanol, acidified ethanol (1\%), and 50\% KMS -Ethanol), sugar level (20\%, $40 \%$, and $60 \%$ ). The intensity of the extracted colour was measured at wavelength $520 \mathrm{~nm}$ using UV-VIS spectrophotometer. The results can elucidate the increasing heating temperature and time, sugar content, and exposure to light is able to spoil the anthocyanin molecule. There was a proportional effect of $\mathrm{pH}$ and oxygen. The anthocyanin stability was found better in $\mathrm{pH}=10$, acidified ethanol (1\%) as extracting solvents, absence of light as processing condition and refrigeration temperature as storage temperature. Hence, these findings could be useful in the food industry to choose a proper processing condition for development of mango powders-based products for satisfying the consumer perception by retaining anthocyanin pigment. shireen_cvasu@yahoo.com mrbadsha1322@gmail.com e@maalim07@yahoo.com

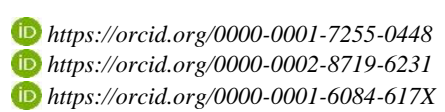

\section{Introduction}

Mango (Mangifera indica L. Anacardiaceae) is a popular subtropical fruit grown in the subtropical regions because of its high economic value. It is reported as the second largest tropical crop next to banana in terms of production, acreage, and popularity (FAO, 2011). Mango is the national fruit in India and Philippines and is the king fruits of Bangladesh (Parvez, 2016). Over 1000 mango varieties are available worldwide. Among the available varieties, only a few are grown on commercial scales and traded (Solis-Fuentes and Duran-de-Bazua, 2011). A huge amount of mango varieties are available in Bangladesh, like Amrapali, Gopalbhog, Himsagar, Langra, Khirsapat, Kohitoor, Chausa, Laksmanbhog, Mallika, Misribhog, Fazlee, Mohanbhog, etc. These varieties of mangoes have commercial importance due to their own demand in food industries (Ara et al., 2014). Amropali is very popular due to its sweetness and non-fibrous flesh.
Mango is consumed as fresh fruit as well as making their cultivation a lucrative proposal to the growers by processed value-added product like juice, pulp, powder, mash, pickles, and syrup (Liu et al., 2014). Fruit powder has enormous economic potential. Dehydration of mango juice into powdered particles gives a considerable reduction in volume and one of an effective method of prolonging the shelf life (Mahendran, 2011). The consumer acceptance of this fruit is high because of its excellent sensory attributes (sweet taste and luscious favour) and specially it is popular in the markets due to it's attractive colors. Anthocyanins are water-soluble pigments that are responsible for the red, blue, and purple colors of most fruits that are classified as flavonoids (Da Costa et al., 2000). The most common anthocyanins in the edible parts of plants are the glycosides of cyanidin, peonidin, pelargonidin, delphinidin, petunidin, and malvidin (Kong 
et al., 2003). Cyanidin-3-O-galactoside and anthocyanidinhexoside are the main anthocyanin compounds found in the red colour of mango fruit peel (Berardini et al., 2005). Anthocyanins act as phytochemical antioxidants with potential health benefits eg. prevention of neuronal diseases, cardiovascular diseases, cancer, and diabetes in human beings (Rahman et al., 2008; Yang et al., 2017; Giampieri et al., 2014; Kong et al., 2003).

There are four different structures of Anthocyanins, namely flavylium cation, carbinol pseudobase, quinoidal base, and chalcon, which are in equilibrium. The relative amounts of anthocyanin structures depend on the $\mathrm{pH}$ (Mazz and Minitiati, 1993). Various factors are responsible for the strength and stability of anthocyanins including $\mathrm{pH}$, temperature, quality and presence of other pigments together, light intensity, metal ions, oxygen, ascorbic acid, sugar, enzymes, and sugar metabolites, sulphur oxide, structure and concentration of the pigments etc (Mazz and Minitiati, 1993; Francis, 1989). Copigmentation is another crucial factor in increasing the stability of the anthocyanin (Francis, 1989; Malien-Aubert et al., 2001). The copigment effect is evident under weakly acid conditions $(\mathrm{pH}$ 4-6) (Castaneda-Ovando et al., 2009). Cabrita et al. (2000) showed that even though six common anthocyanin 3glucosides (i.e., pelargonidin, peonidin, malvidin, cyanidin, petunidin, and delphinidin) displayed the most intense red coloration and the highest stability in aqueous solutions of $\mathrm{pH} \mathrm{1-3,} \mathrm{however,} \mathrm{the} \mathrm{first} \mathrm{three} \mathrm{also} \mathrm{exhibited}$ intense and stable bluish colours at $\mathrm{pH} 8-9$, highlighting the possibility of using them as colorants in alkaline food products. Anthocyanins in foods were found to decrease during processing and storage as temperature rises (Maccarone et al., 1985). Even at lower temperatures, degradation of anthocyanins is still a concern. The degradation rates of anthocyanins increase with increasing solid content during heating, due to the closeness of reacting molecules in juice with higher soluble solid content (Patras et al., 2010). A number of enzymes and oxygen amplifies the impact of anthocyanin degradation processes (Cavalcanti et al., 2011). Sondheimer and Kertesz (1953) suggested that maximal loss of anthocyanins occurred under conditions most favourable to ascorbic acid oxidation. Meschter (1953), Tinsley and Bockian (1960), and Mackinney et al. (1955) observed that the presence of sugars accelerated the degradation of pelargonidin-3-glucoside in strawberry products. Van Buren et al. (1968) found that acylated methylated anthocyanidin diglycosides displayed the greatest stability against light in wines, nonacylated diglycosides were less stable and monoglycosides even less stable.

Thus, anthocyanins color preservation has continuously been a challenge to the food processing industry. Minimally processed ready-to-eat powder-based product have become popular owing to their easy convenience, low maintaining cost, better keeping quality, high nutritional value, and unique sensory characteristics. Moreover, for satisfying the consumer perception, development of mango powders-based products with maintaining anthocyanins colour retention is challenging during processing and storage. Colour retention is an essential indicator for sensory characteristics of products. The identification of the liable stability dependable factors of anthocyanins and its proper processing techniques developments are crucial for industrialization of mango powder products. Hence, it is very important to investigate the stability of anthocyanins in different processing conditions, so that the losses of targeted product can be minimized. However, research on the anthocyanin stability of mango (Amropali variety) cultivar in Bangladesh is not common. Therefore, the aims of the study were to evaluate the degradation stability of anthocyanins at different extraction conditions from dried mango powders.

\section{Materials and Method}

\section{Collection of Mangoes}

The fresh mangoes (Amropali cultivars) were purchased from Rajshahi districts in Bangladesh. The ripe mangoes of uniform colour were selected by visual observation. Then transferred to the laboratory maintaining low temperature $\left(4^{\circ} \mathrm{C}\right)$ before processing. The average weight of mango was $241 \pm 0.12 \mathrm{~g}$.

\section{Preparation of Mango Power}

The mangoes were washed with distilled water and trimmed to remove the stem and blossom end. The mangoes were peeled, cut and removed the seed. Then mango pulp was prepared by a blender (Philips HR7761, China). The basic composition of the collected mango pulp was total soluble solid (TSS) $17 \pm 0.45^{\circ}$ Brix and $\mathrm{pH}$ $4.92 \pm 0.04$. The pulp was spread with $0.5 \mathrm{~cm}$ thickness in a stainless steel tray $\left(14\right.$ inch $\times 8$ inch) and dried at $50^{\circ} \mathrm{C}$ for $48 \pm 2 \mathrm{hrs}$ (up to moisture content $5 \% \mathrm{DB}$ ) in a Cabinet dryer (GENLAB 1000-L Drying Cabinet). The lower temperature was maintained to reduce the loss of phenolic property in dried powder. The dried samples were cool down to room temperature and then ground in a grinder (Panasonic super mixer grinder (MX-AC300), Japan) for total 3 mins ( 3 times-1 min each) at 21000 RPM to obtain a fine powder. Then powder was sieved by a stainless-steel lab test hand sieve (No. 60, mesh size $250 \mu \mathrm{m}$, China) and kept in the refrigerator at $4^{\circ} \mathrm{C}$ till use.

\section{Extract Preparation}

$100 \mathrm{~g}$ dried mango powder transferred into a beaker containing $1000 \mathrm{~mL}$ absolute ethanol as a solvent and shake it on a shaker for 72 hours at room temperature. The extract was filtered by wattman filter paper (grade 1) into a conical flask and filter funnel. The filtrate was collected and stored at room temperature. At the same time, the residue was re-extracted for two times and every time with fresh ethanol solvent. Then, all the filtrates were evaporated using a rotary evaporator (Heidolph ${ }^{\mathrm{TM}} \mathrm{Hei}-$ VAP Value Digital Model) under vacuum pressure at $60^{\circ} \mathrm{C}$ to get the crude extracts. The crude extracts were weighed and then stored at $4{ }^{\circ} \mathrm{C}$ under refrigerated conditions until further analysis.

\section{Total Anthocyanin Content (TAC) Assay}

TAC of the mango powder extracts was determined calorimetrically following the method described with slight modifications (Selim et al., 2008). Stock solutions of $10 \mathrm{mg} / \mathrm{mL}$ of extracts were prepared, then extract solution $(3 \mathrm{~mL})$ was pipetted into a cuvette. The intensity of the extracted color was measured at wavelength $520 \mathrm{~nm}$ using UV-VIS spectrophotometer (UV-2600, Shimadzu). As a 
blank ethanol was used. Total anthocyanin content (TAC) was calculated using the following equation:

$$
\mathrm{TAC}=\frac{\text { Absorbance of the sample } \times \mathrm{DF} \times 100}{\mathrm{~m} \times \mathrm{E}}
$$

Where;

$\mathrm{TAC}=$ Expressed as milligrams per $100 \mathrm{~g}(\mathrm{mg} / 100 \mathrm{~g})$

$\mathrm{DF}=$ Stands for dilution factor

$\mathrm{m}=$ Means the weight of sample used to make a stock solution

$\mathrm{E}=$ Refers to extinction coefficient (55.9)

Each experiment was replicated three times.

\section{Different Processing Temperature Effects}

The sample was put in a capped falcon tube and covered with aluminum foil paper. Then kept at different temperatures ranging from $30^{\circ} \mathrm{C}, 60^{\circ} \mathrm{C}$ and $80^{\circ} \mathrm{C}$ for 10,20 and 30 minutes each, respectively. Then follow the previously described method for TAC to find the effect of anthocyanin stability at different temperatures.

\section{Storage Conditions Effects}

To study the influence of natural light on the stability of anthocyanin pigment, the sample was put in a capped falcon tube and covered with aluminum foil paper then stored in the light and the dark condition, respectively. For observing the influence of storage temperature on anthocyanins, the sample was put in a capped falcon tube and covered with aluminum foil paper then were kept at room temperature $\left(30^{\circ} \mathrm{C}\right)$, freezing temperature $\left(-18^{\circ} \mathrm{C}\right)$ and refrigerator temperature $\left(4^{\circ} \mathrm{C}\right)$ respectively. Then all samples were measured TAC by following the previously described methods for 7 days intervals, respectively up to 28 days.

\section{pH effects}

For determination of anthocyanin solubility on different $\mathrm{pH}$, the following buffers were used: (a) $\mathrm{pH}=2$ and 3 (0.13 M HCl -0.05 M KCl); (b) pH=4 (REAGECON) (c) $\mathrm{pH}=7$ (REAGECON) and (d) $\mathrm{pH}=10$ (REAGECON) (Reagecon Diagnostics Ltd. Shannon Free Zone, Shannon V14 X073, Co. Clare, Ireland). Then, samples and respected buffer were mixture and then equilibrated in the dark condition. Then their absorbance was measured for seven days intervals for each sample up to 28 days by following the previously described method for TAC.

\section{Oxygen Exposed Effects}

Regarding the influence of oxygen, the stability of anthocyanin's extract was exposed to air bubbling in a bioreactor (Sartorius stedim, BIOSTATA) for $4 \mathrm{hr}$. Then their absorbance was measured by following the previously described method for TAC. The data for TAC were recorded for 7 days intervals up to 28 days by repeating the same procedure.

\section{Different Extracting Solvent Effects}

To find the influence of different extracting solvent, $10 \mathrm{~g}$ dried mango powder was mixed with $100 \mathrm{~mL}$ of methanol, absolute ethanol, acidified ethanol (1\%), and 50\% KMS (Potassium metabisulfite)-Ethanol respectively in amber glass bottles. Then TAC was recorded by following the previously described method. The data were recorded for seven days intervals for each sample up to 28 days.

\section{Sugar Percentage Effects}

Three various percentages of sucrose were used. Firstly, the $\mathrm{pH}$ of anthocyanin extract sample was controlled $(\mathrm{pH}=2)$ by $\mathrm{pH}$ meter. Then sugar $(20 \%, 40 \%$, and $60 \%$ respectively) was mixed with the sample and kept in dark condition at room temperature. The quantity of anthocyanin absorbance was recorded by following the previously described method. The data for each sample was recorded for seven days intervals for up to 28 days.

\section{Statistical Analysis}

Each evaluation was done at least three times, and the data were expressed as a mean value with standard deviation (SD). All obtained data in this investigation were analyzed by one-way ANOVA (Tukey's Multiple Comparison Test) using Statistical Package for the Social Sciences (SPSS) version 23. A significant difference was considered at the level of $\mathrm{P}<0.05$.

\section{Results and Discussions}

\section{The Effect of Temperature On the Stability of Anthocyanin}

Table 1 showed the total anthocyanin content $(\mathrm{mg} / 100 \mathrm{~g})$ of mango powder with different heating temperature $\left(30^{\circ}\right.$, $60^{\circ}$ and $80^{\circ} \mathrm{C}$ ) for 10,20 , and 30 minutes, respectively. Temperature is a leading factor, which has an adverse role in destabilizing the anthocyanin molecular structure (Cavalcanti et al., 2011). Table 1 shows that increasing heating temperature and time resulted in decreases anthocyanin content in mange powder.

Table 1. TAC $(\mathrm{mg} / 100 \mathrm{~g})$ of mango powder at a different heating temperature during storage

\begin{tabular}{l|ccc}
\multicolumn{2}{c}{ Heating Temp $\left({ }^{\circ} \mathrm{C}\right)$} & \multicolumn{3}{c}{ Heating Time (min) } \\
\cline { 2 - 4 } & 10 & 20 & 30 \\
\hline Without heat expose (control) & $2.11 \pm 0.02^{\mathbf{a}}$ & $2.11 \pm 0.02^{\mathbf{a}}$ & $2.11 \pm 0.02^{\mathbf{a}}$ \\
30 & $1.93 \pm 0.07^{\mathbf{a}}$ & $1.76 \pm 0.1^{\mathbf{b}}$ & $1.76 \pm 0.1^{\mathbf{b}}$ \\
60 & $1.64 \pm 0.21^{\mathbf{a}}$ & $1.47 \pm 0.1^{\mathbf{c}}$ & $1.33 \pm 0.1^{\mathbf{c}}$ \\
80 & $1.62 \pm 0.31^{\mathbf{a}}$ & $1.37 \pm 0.11^{\mathbf{c}}$ & $1.16 \pm 0.02^{\mathbf{c}}$ \\
\hline F-test & $4.645^{*}$ & $42.097^{* *}$ & $104.261^{* *}$ \\
\hline
\end{tabular}

** Significant at $\mathrm{P}<0.01$, *Significant at $\mathrm{P}<0.05$; Values followed by different superscript letters denote a significant difference; the comparison is made across the days. Results are means \pm standard deviation of triplicates $(n=3)$ 
Table-2. TAC (mg/100g) of mango powder at different Storage temperature and under the influence of light

\begin{tabular}{l|lcccc}
\hline \multirow{2}{*}{ Days } & \multicolumn{3}{c}{ Light } \\
\cline { 2 - 6 } & $\begin{array}{c}\text { Room Temp } \\
(30 \mathrm{C})\end{array}$ & $\begin{array}{c}\text { Refrigeration Temp } \\
\left(4^{\circ} \mathrm{C}\right)\end{array}$ & $\begin{array}{c}\text { freezing Temp } \\
\left(-18^{\circ} \mathrm{C}\right)\end{array}$ & $\begin{array}{c}\text { In the presence of } \\
\text { light }\end{array}$ & $\begin{array}{c}\text { In the absence of } \\
\text { light }\end{array}$ \\
\hline 0 & $1.42 \pm 0.1^{\mathbf{a}}$ & $1.42 \pm 0.1^{\mathbf{a}}$ & $1.42 \pm 0.1^{\mathbf{a}}$ & $1.42 \pm 0.1^{\mathbf{a}}$ & $1.42 \pm 0.1^{\mathbf{a}}$ \\
7 & $1.42 \pm 0.1^{\mathbf{a}}$ & $1.42 \pm 0.1^{\mathbf{a}}$ & $1.42 \pm 0.1^{\mathbf{a}}$ & $1.24 \pm 0.09^{\mathbf{a}}$ & $1.42 \pm 0.1^{\mathbf{a}}$ \\
14 & $1.41 \pm 0.05^{\mathbf{a}}$ & $1.42 \pm 0.1^{\mathbf{a}}$ & $1.41 \pm 0.05^{\mathbf{a}}$ & $0.97 \pm 0.1^{\mathbf{b}}$ & $1.41 \pm 0.05^{\mathbf{a}}$ \\
21 & $1.38 \pm 0.001^{\mathbf{a}}$ & $1.42 \pm 0.1^{\mathbf{a}}$ & $1.38 \pm 0.001^{\mathbf{a}}$ & $0.88 \pm 0.03^{\mathbf{b}}$ & $1.38 \pm 0.001^{\mathbf{a}}$ \\
28 & $1.34 \pm 0.003^{\mathbf{a}}$ & $1.48 \pm 0.1^{\mathbf{a}}$ & $1.34 \pm 0.003^{\mathbf{a}}$ & $0.78 \pm 0.1^{\mathbf{b}}$ & $1.34 \pm 0.003^{\mathbf{a}}$ \\
\hline F-test & $0.875^{\mathbf{N S}}$ & $0.016^{\mathbf{N S}}$ & $0.875^{\mathbf{S S}}$ & $22.368^{* *}$ & $0.875^{\mathbf{S S}}$ \\
\hline
\end{tabular}

** Significant at $\mathrm{P}<0.01$; Values followed by different superscript letters denote a significant difference; the comparison is made across the days. $\mathrm{NS}=$ not significant. Results are means \pm standard deviation of triplicates $(\mathrm{n}=3)$.

Table-3. TAC (mg/100g) of mango powder at different extracting solvent

\begin{tabular}{l|cccc}
\hline \multicolumn{1}{c}{ Days } & Methanol & $1 \%$ acidified ethanol & $50 \%$ KMS+50\% absolute ethanol & Absolute ethanol \\
\hline 0 & $24.8 \pm 4.1^{\mathbf{a}}$ & $23.68 \pm 0.94^{\mathbf{a}}$ & $148.48 \pm 3.08^{\mathbf{a}}$ & $1.42 \pm 0.1^{\mathbf{a}}$ \\
7 & $15.9 \pm 0.01^{\mathbf{b}}$ & $14.87 \pm 1.03^{\mathbf{b}}$ & $129.86 \pm 2.98^{\mathbf{b}}$ & $1.42 \pm 0.1^{\mathbf{a}}$ \\
14 & $14.87 \pm 1.03^{\mathbf{b}}$ & $11.65 \pm 0.67^{\mathbf{c}}$ & $120.57 \pm 3^{\mathbf{c}}$ & $1.41 \pm 0.05^{\mathbf{a}}$ \\
21 & $14.87 \pm 1.03^{\mathbf{b}}$ & $9.12 \pm 0.89^{\mathbf{d}}$ & $118.42 \pm 3^{\mathbf{c}}$ & $1.38 \pm 0.001^{\mathbf{a}}$ \\
28 & $14.87 \pm 1.03^{\mathbf{b}}$ & $9.12 \pm 0.89^{\mathbf{d}}$ & $79.42 \pm 3^{\mathbf{d}}$ & $1.34 \pm 0.003^{\mathbf{a}}$ \\
\hline F-test & $14.165^{* *}$ & $138.607^{* *}$ & $211.127^{* *}$ & $0.875^{\text {NS }}$ \\
\hline
\end{tabular}

** Significant at $\mathrm{P}<0.01$; Values followed by different superscript letters denote a significant difference; the comparison is made across the days. $\mathrm{NS}=$ not significant. Results are means \pm standard deviation of triplicates $(\mathrm{n}=3)$.

The anthocyanin was destructed in higher temperature because of hydrolyzation of 3-Glycoside structure (has a protective effect in the stability of anthocyanin). Another reason could be hydrolyzation of the pyrylium ring resulted in production of chalcone, which are responsible for brown colour (Giusti and Wrolstad, 2001). A similar effect was found by Saravanakumar and Aravindhan (2011). Palamidis and Markakis (1975) have studied anthocyanins stability in soft drinks that increases the storage temperature significantly accelerate the destruction of colours in soft drinks. Maccarone et al. (1985) have found the effect of anthocyanin in red-orange juice at different temperatures $\left(15^{\circ} \mathrm{C}, 25^{\circ} \mathrm{C}\right.$ and $\left.35^{\circ} \mathrm{C}\right)$ during a 15 -day period and concluded that the decolourization or destruction of anthocyanins occurs due to increase in temperature. Meschter (1953) stated that the time for 50\% destruction (half-life) of anthocyanin pigment in strawberry preserve at $100^{\circ} \mathrm{C}$ was $1 \mathrm{hr}$; the half-life was ten days during storage at $38^{\circ} \mathrm{C}$; the half-life was 54 days during storage at $20^{\circ} \mathrm{C}$ and the pigment half-life would be expected to be 11 months during storage at $0^{\circ} \mathrm{C}$.

The Effect of Storage Temperature and Storage Period On the Stability of Anthocyanin

Table 2 shows that the effect of room temperature $\left(30^{\circ} \mathrm{C}\right)$, refrigeration temperature $\left(4^{\circ} \mathrm{C}\right)$ and freezing temperature $\left(-18^{\circ} \mathrm{C}\right)$ on the stability profile of anthocyanin content during storage for 28 days. There was no significant difference of anthocyanin content among these storage temperatures. But the total anthocyanin content was slightly decreased after twenty days of storage periods. Therefore, the colour loss of the anthocyanins pigment was most obvious at higher storage periods. On the other hand, an increase in total anthocyanins content during frozen storage have achieved eg. red raspberries (Syamaladevi et al., 2011; De Ancos et al., 2000); sour cherries (Urbanyi and Horti, 1992); strawberries (Oszmianski et al., 2009) and serviceberries (Michalczyk and Macura, 2010) due to tissue softening enhanced extraction of anthocyanins
(Hager et al., 2008). Although previous studies were found that there were no significant change in total anthocyanins in frozen storage of fruits e.g., clarified pomegranate juice (Turfani et al., 2012), black carrot juice (Turkyimaz and Ozkan, 2012), black raspberries (Hager et al., 2008), red raspberries (Sousa et al., 2005; Mullen et al., 2002), and blueberries (Lohachoompol et al., 2004). Apart from that, De Ancos et al. (2000) revealed that frozen storage affects total anthocyanin content depending on the cultivar of fruits. Therefore, it is suggested that the decolorizing effect might be due to the mango cultivars variety, storage condition and plant chemical composition, etc.

\section{The Effect of Light On the Anthocyanin's Stability of Mango Powder}

Light exposure is sensitive and essential factor, which significantly affects the anthocyanins stability. The effect of light on total anthocyanin content in the cabinet dried mango powder has been presented in Table 2. The anthocyanin content was higher in the absence of light. There were no significant differences in anthocyanin in the case of the absence of light during storage. But in case of presence of light, anthocyanin content had changed significantly after 7 days exposure. Moreover, Palamidis and Markakis (1975) have shown the adverse destruction effect of light in grape juice, exhibited that almost $30 \%$ of the pigments were destroyed, after placing the juice samples containing anthocyanin in dark for 135 days at $20^{\circ} \mathrm{C}$ but more than $50 \%$ of total pigments destroyed after placing the same samples in the same temperature and same period of time in the presence of light. Stanciu et al. (2010) also found the impact of light exposure throughout one month on anthocyanins extracts, in which losses of anthocyanins content were $37.91 \%$ (861.206 to 534.947 $\mathrm{mg} / 100 \mathrm{~g}$ fresh product), $68.14 \%$ (500.267 to 159.376 $\mathrm{mg} / 100 \mathrm{~g}$ fresh product) and $89.48 \%$ (501.358 to 52.71 $\mathrm{mg} / 100 \mathrm{~g}$ fresh product) for three types of extracts respectively from black grape skin (Vitis vinifera). 
Table-4. TAC (mg/100g) of mango powder at different Sugar level

\begin{tabular}{l|cccc}
\hline \multirow{2}{*}{ Days } & $\begin{array}{c}\text { Control } \\
\text { (no sugar added) }\end{array}$ & $\begin{array}{c}\text { Extract with } \\
20 \% \text { Sugar }\end{array}$ & $\begin{array}{c}\text { Extract with } \\
40 \% \text { Sugar }\end{array}$ & $\begin{array}{c}\text { Extract with } \\
60 \% \text { Sugar }\end{array}$ \\
\hline 0 & $1.42 \pm 0.1^{\mathbf{a}}$ & $1.56 \pm 0.02^{\mathbf{a}}$ & $1.38 \pm 0.1^{\mathbf{a}}$ & $1.16 \pm 0.02^{\mathbf{a}}$ \\
7 & $1.42 \pm 0.1^{\mathbf{a}}$ & $0.32 \pm 0.09^{\mathbf{b}}$ & $0.27 \pm 0.1^{\mathbf{b}}$ & $0.25 \pm 0.01^{\mathbf{b}}$ \\
14 & $1.41 \pm 0.05^{\mathbf{a}}$ & $0.13 \pm 0.01^{\mathbf{c}}$ & $0.09 \pm 0.001^{\mathbf{c}}$ & $0.05 \pm 0.02^{\mathbf{c}}$ \\
21 & $1.38 \pm 0.001^{\mathbf{a}}$ & $0.09 \pm 0.001^{\mathbf{c}}$ & $0.07 \pm 0.01^{\mathbf{c}}$ & $0.07 \pm 0.01^{\mathbf{c}}$ \\
28 & $1.34 \pm 0.003^{\mathbf{a}}$ & $0.07 \pm 0.01^{\mathbf{c}}$ & $0.07 \pm 0.01^{\mathbf{c}}$ & $0.04 \pm 0.02^{\mathbf{c}}$ \\
\hline F-test & $0.875^{\mathrm{NS}}$ & $639.884^{* *}$ & $237.773^{* *}$ & $2524^{* *}$ \\
\hline
\end{tabular}

** Significant at $\mathrm{P}<0.01$; Values followed by different superscript letters denote a significant difference; comparison is done across the days. NS=not significant. Results are means \pm standard deviation of triplicates $(\mathrm{n}=3)$.

Table-5. TAC (mg/100g) of mango powder at different $\mathrm{pH}$

\begin{tabular}{l|llllll}
\hline \multirow{2}{*}{ Days } & \multirow{2}{*}{ Control } & \multicolumn{5}{c}{$\mathrm{pH}$} \\
\cline { 2 - 6 } & & \multicolumn{1}{c}{2} & \multicolumn{5}{c}{4} & \multicolumn{1}{c}{} \\
\hline 0 & $1.42 \pm 0.1^{\mathbf{a}}$ & $2.4 \pm 0.43^{\mathbf{a}}$ & $2.82 \pm 0.18^{\mathbf{a}}$ & $4.38 \pm 1.95^{\mathbf{a}}$ & $4.45 \pm 0.01^{\mathbf{a}}$ & $4.88 \pm 0.03^{\mathbf{a}}$ \\
7 & $1.42 \pm 0.1^{\mathbf{a}}$ & $0.32 \pm 0.1^{\mathbf{b}}$ & $0.28 \pm 0.01^{\mathbf{b}}$ & $1.67 \pm 0.22^{\mathbf{b}}$ & $1.96 \pm 0.3^{\mathbf{b}}$ & $3.47 \pm 1.1^{\mathbf{b}}$ \\
14 & $1.41 \pm 0.05^{\mathbf{a}}$ & $0.23 \pm 0.1^{\mathbf{b}}$ & $0.09 \pm 0.001^{\mathbf{b c}}$ & $1.34 \pm 0.11^{\mathbf{b}}$ & $1.74 \pm 0.1^{\mathbf{b}}$ & $2.82 \pm 0.8^{\mathbf{a b}}$ \\
21 & $1.38 \pm 0.001^{\mathbf{a}}$ & $0.05 \pm 0.002^{\mathbf{b}}$ & $0.09 \pm 0.001^{\mathbf{b c}}$ & $0.77 \pm 0.11^{\mathbf{b}}$ & $1.62 \pm 0.2^{\mathbf{b c}}$ & $2.68 \pm 0.8^{\mathbf{a b}}$ \\
28 & $1.34 \pm 0.003^{\mathbf{a}}$ & $0.04 \pm 0.002^{\mathbf{b}}$ & $0.04 \pm 0.002^{\mathbf{c}}$ & $0.44 \pm 0.2^{\mathbf{b}}$ & $1.27 \pm 0.01^{\mathbf{c}}$ & $2.42 \pm 1.1^{\mathbf{b}}$ \\
\hline F-test & $0.875^{\mathrm{NS}}$ & $73.582^{* *}$ & $650.339^{* *}$ & $9.366^{* *}$ & $193.215^{* *}$ & $3.78^{*}$ \\
\hline
\end{tabular}

** Significant at $\mathrm{P}<0.01$, *significant at $\mathrm{p}<0.05$; Values followed by different superscript letters denote a significant difference; the comparison is made across the days. NS=not significant Results are means \pm standard deviation of triplicates $(n=3)$

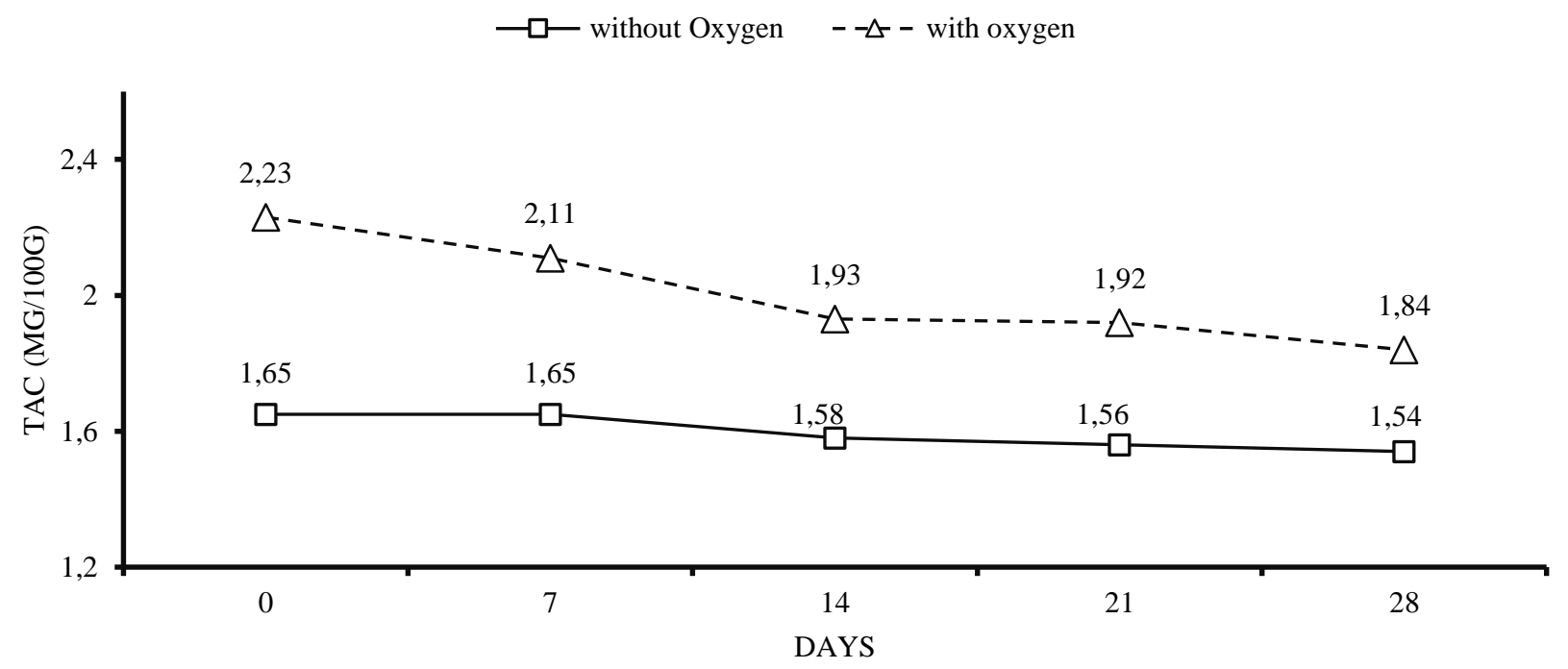

Figure 1. Effect of oxygen

\section{Effect of Different Extracting Solvent on TAC}

Table 3 shows the effect of different extracting solvent on the total extraction percentages of anthocyanin. From the experimental results, it represents that total anthocyanin obtained from 50\% KMS+50\% absolute ethanol were the highest in terms of amount at the end of the duration among the four extracting solvents but in terms of stability percentage of total anthocyanin content (60\% approximately) were the highest in case of methanol at the end of the duration. Similar results were reported by Kopjar et al. (2014) that the most efficient extraction solvent was methanol acidified with hydrochloric acid among water and ethanol acidified forms for anthocyanin extraction from sour cherry puree extracts. However, Oancea et al. (2012) found that good recovery of anthocyanins from blueberry samples were obtained with $50 \%$ ethanol than that of others ((1) water; (2) ethanol/acetic acid/water (50/2/48); (3) ethanol/0.1 N hydrochloric acid (95/15); (4) $80 \%$ ethanol (v/v); (5) $70 \%$ ethanol (v/v); (6) $60 \%$ ethanol (v/v)). For plant materials, the almost universal approach is to treat the sample with a solution of $1 \%$ hydrochloric acid in methanol. For foods, $1 \% \mathrm{HCl}$ in ethanol may be preferred, due to the toxicity of methanol, even though it is slightly less effective in the extraction and more difficult to concentrate (Francis, 1982).

\section{The Effect of Sugar Percentages}

Table 4 represent the effect of sugar percentages on the stability of anthocyanin pigment in mango powder. The anthocyanin content decreases at three different percentages of sugar $(20,40$, and $60 \%)$ during storage for 28 days. However, higher anthocyanins value was found in the concentration of $20 \%$ sugar $(1.56 \mathrm{mg} / 100 \mathrm{~g})$, which 
indicates moderate concentration of sugar could preserve anthocyanins in the mango powder. The results agree with the previous results carried out by Nikkhah et al. (2007) that primary concentration (20\%) of sugar (sucrose) has a caring effect on anthocyanin but decreased in higher concentration. Principally, sugars are naturally present in fruits, and during the food preparation process, usually, sugar added to different products such as jams, jelly, and fruit extracts but sugars decreased stability of anthocyanins (Meschter, 1953; Thakur and Arya, 1989). Daravingas and Cain (1968) tested all sugars (sucrose, fructose, glucose, and xylose) which shows increased amount of sugar is responsible for anthocyanins degradation. Additionally, Anthocyanin reactions with destructed production of sugar cause the formation of brown-colour polymerized pigments (Krifi et al., 2000).

\section{The Effect of Oxygen on the Anthocyanin's Stability of Mango Powder}

Figure 1 exhibited that the total anthocyanin content decreased insignificantly during storage with and without oxygen exposure. The anthocyanin content is higher when oxygen is exposed. Stanciu et al. (2010) also found that anthocyanins extracts subjected to air bubbling for eight hrs period demonstrate an increase in colour pigments, which might be resulted from direct oxidative mechanism increasing brown products formation which further reacts with anthocyanins giving rise to brown products.

\section{The Effect of pH on The Anthocyanin's Stability of Mango Powder}

According to Table 5, anthocyanin increased with increases of $\mathrm{pH}$ where it was stable at $\mathrm{pH}=7$ and $\mathrm{pH}=10$. However, anthocyanin in mango powder decreased during storage at all $\mathrm{pH}$ conditions. For $\mathrm{pH}=10$ mango samples have the highest value of anthocyanins $(4.88 \mathrm{mg} / 100 \mathrm{gm})$. Little (1977) showed that the destruction of anthocyanin pigments increases with an increase of $\mathrm{pH}$ in packaged Strawberries and Strawberry jam at $37.7^{\circ} \mathrm{C}$ during storage. Laleh et al. (2006) also found a similar effect for Berberis Species.

\section{Conclusion}

In order to obtain the level of influence on total anthocyanin content, which may influence the quality of the final product, various parameters were optimized (extraction solvent, processing temperature and time, storage temperatures, influence of light, sugar level, oxygen, $\mathrm{pH}$ for 28 days storage). The findings conclude that increase in heating temperature, time, sugar content, and exposure to light result in the degradation of anthocyanin content. Selected conditions for anthocyanin stability were $\mathrm{pH}=10$, acidified ethanol $(1 \%)$ as extracting solvents, refrigeration temperature as storage temperature, $20 \%$ sugar content, $30^{\circ} \mathrm{C}$ as heating temperature, and the presence of oxygen. The present experimental studies would undoubtedly help to select the perfect condition for processing and storage and preparing further product from mango powder without any losses of this valuable pigments. Further investigation will be carried out to develop and evaluate anthocyanin's rich powder-based product.

\section{References}

Ara R, Motalab M, Uddin M, Fakhruddin A, Saha B. 2014. Nutritional evaluation of different mango varieties available in Bangladesh. International Food Research Journal, 21(6): 2169-2174.

Berardini N, Fezer R, Conrad J, Beifuss U, Carle R, Schieber A. 2005. Screening of mango (Mangifera indica L.) cultivars for their contents of flavonol O-and xanthone C-glycosides, anthocyanins, and pectin. Journal of agricultural and food chemistry, 53(5): 1563-1570.

Cabrita L, Fossen T, Andersen OM. 2000. Colour and stability of the six common anthocyanidin 3-glucosides in aqueous solutions. Food chemistry, 68(1): 101-107.

Castaneda-Ovando A, de Lourdes Pacheco-Hernandez M, PaezHernandez ME, Rodríguez JA, Galan-Vidal CA. 2009. Chemical studies of anthocyanins: A review. Food chemistry, 113(4): 859-871.

Cavalcanti RN, Santos DT, Meireles MAA. 2011. Non-thermal stabilization mechanisms of anthocyanins in model and food systems An overview. Food research international, 44(2): 499-509.

Da Costa CT, Horton D, Margolis SA. 2000. Analysis of anthocyanins in foods by liquid chromatography, liquid chromatography-mass spectrometry and capillary electrophoresis. Journal of Chromatography A, 881(1-2): 403-410.

Daravingas G, Cain R. 1968. Thermal degradation of black raspberry anthocyanin pigments in model systems. Journal of Food Science, 33(2): 138-142.

Davies A, Mazza G. 1993. Copigmentation of simple and acylated anthocyanins with colorless phenolic compounds. Journal of Agricultural and Food Chemistry, 41(5): 716-720.

De Ancos B, Gonzalez E, Cano MP. 1999. Differentiation of raspberry varieties according to anthocyanin composition. Zeitschrift für Lebensmitteluntersuchung und-Forschung A, 208(1): 33-38.

De Ancos B, Ibanez E, Reglero G, Cano MP. 2000. Frozen storage effects on anthocyanins and volatile compounds of raspberry fruit. Journal of Agricultural and Food Chemistry, 48(3): 873-879.

FAO F. 2011. Available online at: http://faostat. fao. org/site/291/default. aspx. Food and Agriculture Organization.

Fleschhut J, Kratzer F, Rechkemmer G, Kulling SE. 2006. Stability and biotransformation of various dietary anthocyanins in vitro. European journal of nutrition, 45(1): 7-18.

Francis F. 1982. Analysis of anthocyanins. In: Markakis P. Anthocyanins as food colors, $1^{\text {st }} \mathrm{ed}$, Academic Press, pp. 280.

Francis FJ, Markakis PC. 1989. Food colorants: anthocyanins. Critical Reviews in Food Science and Nutrition, 28(4): 273-314.

Franke AA, Custer LJ, Arakaki C, Murphy SP. 2004. Vitamin C and flavonoid levels of fruits and vegetables consumed in Hawaii. Journal of Food Composition and Analysis, 17(1): 1-35.

Giampieri F, Alvarez-Suarez JM, Mazzoni L, Forbes-Hernandez TY, Gasparrini M, Gonza`lez-Parama`s AM, Santos-Buelga C, Quiles JL, Bompadre S, Mezzetti B, Battino M. 2014. An anthocyaninrich strawberry extract protects against oxidative stress damage and improves mitochondrial functionality in human dermal fibroblasts exposed to an oxidizing agent. Food Funct, 5:1939-1948.

Giusti MM, Wrolstad RE. 2001. Characterization and Measurement of Anthocyanins by UV-Visible Spectroscopy. Current Protocols in Food Analytical Chemistry, 1: F1.2.1F1.2.13.

Hager A, Howard L, Prior R, Brownmiller C. 2008. Processing and storage effects on monomeric anthocyanins, percent polymeric color, and antioxidant capacity of processed black raspberry products. Journal of Food Science, 73(6): H134H140. 
JR M, Sistrunk W, Junek J, Sims C. 1986. Effects of fruit maturity, juice storage, and juice extraction temperature on quality of concord 'grape juice. Journal of the American Society for Horticultural Science, 111(5): 742-746.

Kong JM, Chia LS, Goh NK, Chia TF, Brouillard R. 2003. Analysis and biological activities of anthocyanins. Phytochemistry, 64(5): 923-933.

Kopjar M, Orsolic M, Pilizota V. 2014. Anthocyanins, phenols, and antioxidant activity of sour cherry puree extracts and their stability during storage. International journal of food properties, 17(6): 1393-1405.

Krifi B, Metche M. 2000. Degradation of anthocyanins from blood orange juices. International Journal of Food Science and Technology, 35(3): 275-283.

Laleh G, Frydoonfar H, Heidary R, Jameei R, Zare S. 2006. The effect of light, temperature, $\mathrm{pH}$ and species on stability of anthocyanin pigments in four Berberis species. Pakistan Journal of Nutrition, 5(1): 90-92.

Little AC. 1977. Colorimetry of anthocyanin pigmented products: changes in pigment composition with time. Journal of Food Science, 42(6): 1570-1574.

Liu F, Li R, Wang Y, Bi X, Liao X. 2014. Effects of high hydrostatic pressure and high-temperature short-time on mango nectars: Changes in microorganisms, acid invertase, 5-hydroxymethylfurfural, sugars, viscosity, and cloud. Innovative Food Science and Emerging Technologies, 22: 22 30.

Lohachoompol V, Srzednicki G, Craske J. 2004. The change of total anthocyanins in blueberries and their antioxidant effect after drying and freezing. BioMed Research International, 5: 248-252.

Maccarone E, Maccarrone A, Rapisarda P. 1985. Stabilization of anthocyanins of blood orange fruit juice. Journal of Food Science, 50(4): 901-904.

Mackinney G, Lukton A, Chichester C. 1955. Strawberry preserves by a low temperature process. Food Technology, 9: 324.

Mahendran T. 2011. Physico-chemical properties and sensory characteristics of dehydrated guava concentrate: effect of drying method and maltodextrin concentration. Tropical Agricultural Research and Extension, 13(2): 48-54.

Malien-Aubert C, Dangles O, Amiot MJ. 2001. Color stability of commercial anthocyanin-based extracts in relation to the phenolic composition. Protective effects by intra-and intermolecular copigmentation. Journal of Agricultural and Food Chemistry, 49(1): 170-176.

Mazza G, Miniati E. 1993. Small fruits. Anthocyanins in Fruits, Vegetables and Grains, CRC Press, Boca Raton, London, pp. 85-129.

Meschter EE. 1953. Fruit color loss, effects of carbohydrates and other factors on strawberry products. Journal of Agricultural and Food Chemistry, 1(8): 574-579.

Michalczyk M, Macura R, 2010. Effect of processing and storage on the antioxidant activity of frozen and pasteurized shadblow serviceberry (Amelanchier canadensis). International Journal of Food Properties, 13(6): 1225-1233.

Mullen W, Stewart AJ, Lean ME, Gardner P, Duthie GG, Crozier A. 2002. Effect of freezing and storage on the phenolics, ellagitannins, flavonoids, and antioxidant capacity of red raspberries. Journal of Agricultural and Food Chemistry, 50(18): 5197-5201.

Nikkhah E, Khayamy M, Heidari R, Jamee R. 2007. Effect of sugar treatment on stability of anthocyanin pigments in berries. Journal of Biological Sciences, 7(8): 1412-1417.

Oancea S, Stoia M, Coman D. 2012. Effects of extraction conditions on bioactive anthocyanin content of Vaccinium corymbosum in the perspective of food applications. Procedia Engineering, 42: 489-495.
Oszmianski J, Wojdylo A, Kolniak J. 2009. Effect of L-ascorbic acid, sugar, pectin and freeze-thaw treatment on polyphenol content of frozen strawberries. LWT-Food Science and Technology, 42(2): 581-586.

Palamidis N, Markakis P. 1975. Stability of grape anthocyanin in a carbonated beverage. Journal of Food Science, 40(5), 10471049.

Parvez GM. 2016. Pharmacological activities of mango (Mangifera Indica): A review. Journal of Pharmacognosy and Phytochemistry, 5(3): 1-7

Patras A, Brunton NP, Odonnell C, Tiwari B. 2010. Effect of thermal processing on anthocyanin stability in foods; mechanisms and kinetics of degradation. Trends in Food Science and Technology, 21(1): 3-11.

Rahman M, Ichiyanagi T, Komiyama T, Sato S, Konishi T. 2008. Effects of anthocyanins on psychological stress-induced oxidative stress and neurotransmitter status. J Agric Food Chem, 56(16): 7545-7550.

Saravanakumar M, Aravindhan K. 2011. The effect of light, temperature, $\mathrm{pH}$ on stability of anthocyanin pigments in Musa acuminata bract. Research in plant biology, 1(5): 5-12.

Selim K, Khalil K, Abdel-Bary M, Abdel-Azeim N. 2008. Extraction, encapsulation and utilization of red pigments from roselle (Hibiscus sabdariffa L.) as natural food colourants. Alex Journal of Food Science and Technology, special volume conference: 7-20.

Solís-Fuentes JA, del Carmen Duran-de-Bazua M. 2011. Mango (Mangifera indica L.) seed and its fats. In Nuts and Seeds in health and disease prevention. Academic Press, Elsevier, pp. 741-748.

Sondheimer E, Kertesz Z. 1953. Participation of ascorbic acid in the destruction of anthocyanin in strawberry juice and model systems a. Journal of Food Science, 18(1-6): 475-479.

Sousa MB, Canet W, Alvarez MD, Tortosa ME. 2005. The effect of the pre-treatments and the long and short-term frozen storage on the quality of raspberry (cv. Heritage). European Food Research and Technology, 221(1-2): 132-144.

Stanciu G, Lupsor S, Sava C, Zagan S. 2010. Spectrophotometric study on stability of anthocyanins extracts from black grapes skins. Ovidius University Annals of Chemistry, 21(1): 101104.

Syamaladevi RM, Sablani SS, Tang J, Powers J, Swanson BG. 2011. Stability of anthocyanins in frozen and freeze-dried raspberries during long-term storage: in relation to glass transition. Journal of food science, 76(6): E414-E421.

Thakur B, Arya S. 1989. Studies on stability of blue grape anthocyanins. International Journal of Food Science and Technology, 24(3): 321-326.

Tinsley IJ, Bockian A. 1960. Some effects of sugars on the breakdown of pelargonidin-3-glucoside in model systems at $90^{\circ} \mathrm{C}$ a, b. Journal of Food Science, 25(2): 161-173.

Turfan O, Turkyilmaz M, Yemls O, Ozkan M. 2012. Effects of clarification and storage on anthocyanins and color of pomegranate juice concentrates. Journal of Food Quality, 35(4): 272-282.

Turkyılmaz M, Ozkan M. 2012. Kinetics of anthocyanin degradation and polymeric colour formation in black carrot juice concentrates during storage. International Journal of Food Science and Technology, 47(11): 2273-2281.

Urbanyi G, Horti K. 1992. Changes of surface colour of the fruit and of the anthocyanin content of sour cherries during frozen storage. Acta alimentaria (Budapest), 21(3-4): 307-323.

Van Buren J, Bertino J, Robinson W. 1968. The stability of wine anthocyanins on exposure to heat and light. American Journal of Enology and Viticulture, 19(3): 147-154.

Yang L, Ling W, Du Z, Chen Y, Li D, Deng S, Liu Z, Yang L. 2017. Effects of anthocyanins on cardiometabolic health: a systematic review and meta-analysis of randomized controlled trials. Adv Nutr, 8(5):684-693 